\title{
Hastane Çalışma Birimleri Ayrımında İş Kazalarının İncelenmesi: Ameliyathane Hemşireleri için İş Sağlığı ve Güvenliği Riskleri
}

\author{
Investigation of Occupational Accidents in Hospital Working Units: \\ Occupational Health and Safety Risks for Operating Room Nurses
}

Mehpare TATLI YÖNDEM

\begin{abstract}
ÖZET
Sağlık kurumları tehlikeli kabul edilen diğer sektörlerden farklılaşan iş sağlığı ve güvenliği risklerine açıktır. Çalışanların gelişmiş uzmanlık düzeyi, yapılan işlerin ve çalışma alanlarının çeşitliliği, sağlık kurumlarında yürütülecek güvenlik programlarının alana özgü niteliklere sahip olmasını gerekli kılmaktadır. Bu çalışmada Türkiye'de bir üniversite hastanesinde anket uygulanarak kolayda örnekleme yöntemi kullanılmıştır. Araştırma kapsamında hemşirelerden oluşan 149 kişilik örneklem grubundan elde edilen verilerle, iş yerlerinde yaralanma ve enfeksiyon riski taşıyan kaza deneyimleri, çalışma ortamının yapısal unsurları açısından incelenmiştir. İncelenen kazalar arasında; iğne ile yaralanma, göze ya da ağıza sıçrama, kesici aletlerle yaralanma, açık yaraya temas ve diğer yaralanma türleri yer almaktadır. Diğer grup kazalar dışında tüm kaza türleri için ameliyathane hemşireleri en yüksek deneyim oranına sahiptir. Bununla birlikte kesici aletlerle yaralanma vakasında ameliyathane hemşireleri diğer gruptaki hemşirelere göre istatistiksel açıdan anlamlı düzeyde daha fazla kaza deneyimlemektedir $(\mathrm{p}<0,05)$. Araştırma sonuçları, çalışma birimleri ayrımında, ameliyathane hemşirelerinin yüksek riskli bir ortamda çalışmakta olduğunu işaret etmektedir.
\end{abstract}

Anahtar Kelimeler: İş sağlığı ve güvenliği, İş kazaları, Yaralanma ve enfeksiyon riski, Ameliyathane hemşireleri

\section{ABSTRACT}

Healthcare institutions are open to occupational health and safety risks that differ from other sectors that are considered dangerous. The advanced level of expertise of the employees, the diversity of the work done and the work areas make it necessary for safety programs to be carried out in health institutions to have field-specific qualifications. In this study, convenience sampling method was used by applying a questionnaire in a university hospital in Turkey. Within the scope of the study, with the data obtained from the 149-person sample group consisting of nurses, the accident experiences at the workplace with the risk of injury and infection have been examined in terms of the structural elements of the working environment. Of the accidents that examined were injury by needles, splashes in the eye or mouth, injuries with sharp objects, contact with an open wound and other types of injuries. Operating room nurses have the highest rate of experience for all accident types, except for other group accidents. On the other hand, operating room nurses experience statistically significantly more accidents than nurses in the other group in cases of injuries with sharp objects $(p<0,05)$. The results of the research indicate that operating room nurses work in a high-risk environment, in terms of differentiating between working units. Keywords: Occupational health and safety, Occupational accidents, Risk of injury and infection, Operating room nurses

Mehpare TATLI YÖNDEM | mehpare.tatll@beun.edu.tr

Zonguldak Bülent Ecevit Üniversitesi, Sağlık Bilimleri Fakültesi, Zonguldak, Türkiye

Zonguldak Bulent Ecevit University, Faculty of Health Sciences, Zonguldak, Turkey 


\section{GİRİŞ}

Çalışma yaşamının fiziksel, sosyal veya psikolojik unsurları, çalışanların sağlık ve iyi oluş halleri üzerinde doğrudan ve ciddi etkilere sahiptir. Çalışma koşullarının neden olabileceği olumsuz etkiler, çalışanlar üzerinde kısa ve uzun vadeli sağlık sorunlarına neden olmaktadır. Bu sebeple iş güvenliğiyle ilgili önlem ve uygulamaların titizlikle ele alınması, iş sözleşmesi tarafları ve ilgili devlet kurumlarının yasal sorumluluğudur.

İş güvenliği, işin yapılması esnasında çalışanların karşılaştığı tehlikelerin, tümüyle ortadan kaldırılması veya kabul edilebilir düzeye indirgenmesi konusunda işveren, işletme yönetimi ve aynı zamanda devlete sorumluluk yükleyen kurallar bütünüdür [1]. İşs sağlığı ise Uluslararası Çalışma Örgütü (International Labour Organization [ILO]) ve Dünya Sağlık Örgütü (World Health Organization [WHO]) tarafından: her türlü işte çalışan iş̧̧ilerin; fiziksel, ruhsal ve sosyal yönden tam anlamı ile iyi olma hallerinin korunması ve geliştirilmesi, çalışma şartlarından ötürü sağlığını yitirmesinin önlenmesi, fizyolojik ve psikolojik yapılarına uygun bir işe yerleştirilmesi ve bunun sürdürülmesi şeklinde tanımlanmaktadır [2].

Türkiye'de 2012 yılında yayımlanan 6331 Sayılı İşs Sağlığı ve Güvenliği (İSG) Kanunu'nda iş kazası: işyerinde veya işin yürütümü nedeniyle meydana gelen, ölüme sebebiyet veren veya vücut bütünlüğünü ruhen ya da bedenen engelli hale getiren olaylar olarak tanımlanmaktadır. Meslek hastalığı ise mesleki risklere maruziyet sonucu ortaya çıkan hastalık olarak ifade edilmiştir [3]. Çalışma yaşamının zorlayıı koşulları nedeniyle iş kazası geçiren veya meslek hastalığına yakalanan insanlar bedensel, psikolojik ve ekonomik güçlüklerle başa çıkmak zorunda kalmaktadır.

Ülkemizde 2009 yılında çıkarılan “İş Sağlığı ve Güvenliğine İlişkin Tehlike Sınıfları Listesi Tebliğı’” ile hastaneler
"Çok Tehlikeli İşler" sınıfına dahil edilmiştir [4]. 30 Haziran 2012 tarih ve 6331 Sayılı İSG Kanunu ile sağlık kuruluşlarına kamu-özel ayrımı yapılmaksızın, işyeri hekimi ve iş güvenliği uzmanı çalıştırma zorunluluğu getirilmiştir [3]. Sağlık Bakanlığı̀nın 2011 yılında yayımladığı "Hasta ve Çalışan Güvenliğinin Sağlanmasına Dair Yönetmelik” ve Çalışma ve Sosyal Güvenlik Bakanlığının 2012 yılında yayımladığı "İş Sağlığı ve Güvenliği Kanunu" ile, İSG hizmetlerinin sağlık çalışanlarının hizmetine sunulmasına olanak sağlanmıştır. Ardından hasta ve sağlık çalışanları için güvenli bir ortamın tesis edilmesi amacıyla, ilgili yönetmelik hükümlerinin uygulanması konusunda hastaneler bilgilendirilmiştir [3-5].

Böylece Türkiye'de sağlık kurumlarında önleyici İş Sağlığı ve Güvenliği uygulamaları hayata geçirilmiştir. Bu uygulamalar; çalışan güvenliği komitelerinin kurulması, güvenlik programlarının hazırlanması, çalışanların sağlık taramalarının yapılması, kişisel koruyucu önlemlerin sağlanması, çalş̧anlara yönelik şiddetin önlenmesi için düzenleme yapılması, enfeksiyonların kontrolü ve önlenmesine yönelik program hazırlanması, beyaz kod uygulamasına geçilmesi ve çalş̧anlara İSG eğitimlerinin verilmesini içermektedir. Bununla birlikte bazı araşıırmaların sonuçları, ülkemizde sağlık kurumlarında, çalışan sağlık ve güvenliğini korumaya yönelik yeterli donanım, personel ve hizmet unsurlarının bazı noktalarda eksiklikleri olduğunu işaret etmektedir $[6,7]$.

Araştırma kapsamında, hemşirelerin meslekte en sık maruz kaldığı iş kazası riskleri hastanelerde görev yapılan birimler ayrımında incelenmektedir. Böylece hastanelerde yüksek riskli ortamlar olarak kabul edilen ameliyathane hemşirelerinin maruz kaldıkları risk unsurları ayrıca ele alınmaktadır.

Hastaneler çalışanların görev, birim ve mesleki koşullar 
nedeniyle çeşitli risklerle karşı karşıya olduğu çalışma alanlarıdır. Hastane birimleri ayrımında farklı iş sağlığı ve güvenliği önlem ve uygulamalarına ihtiyaç duyulmaktadır. Bu çalışma ile hastanelerde çeşitli çalışma birimleri özelinde, önleyici iş sağlı̆̆ı ve güvenliği uygulamalarının ele alınmasına ve ilgili literatüre katkı sağlamak amaçlanmaktadır.

\section{A. Sağlık Çalışanları İçin İş Sağlığı ve Güvenliği Riskleri}

Amerika Birleşik Devletleri Mesleki Güvenlik ve Sağlık İdaresi (Occupational Safety and Health AdministrationUnited States [OSHA-US]) kayıtlarına göre, 2011 yılında Birleşik Devletler'deki hastanelerde, her 100 tam gün çalışan için yılda toplam 253.700 işle ilgili yaralanma ve hastalık kaydedilmiştir [8]. Avrupa verilerine göre sağlık sektöründe meydana gelen iş kazaları, Avrupa ortalamasından \% 34 daha yüksektir. İstatistikler sağlık bakım hizmetlerinin yürütüldügü ortamların, çalışmak için en tehlikeli yerlerden biri olduğunu göstermektedir. Avrupa Birliği bünyesinde sağlık çalışanlarının sektörde karşılaştıkları riskler; biyolojik ajanlar, kas-iskelet sistemi bozuklukları, psikososyal bozukluklar ve kimyasal ajanlar olmak üzere gruplandırilmıştır [2].

Tüm sağlık hizmetleri ortamları; tüberküloz, şiddetli akut solunum sendromu, hepatit, İnsan İmmün Yetmezlik Virüsü (HIV) ve çeşitli enfeksiyonlara neden olan solunum ve kan yoluyla bulaşan patojenler içermektedir. Bununla birlikte sağlık çalışanları dezenfektan ve sterilize edici maddeler gibi tehlikeli kimyasallar, mesleki astıma neden olan ilaçlar ve kanserojen maddelere sıklıkla maruz kalmaktadır. Ergonomik rahatsızlıklara yol açan risk faktörleri, gürültü ve radyasyon gibi fiziksel tehlikeler, sektör çalışanlarının sağlığını tehdit etmektedir. Mesleki tehlike kategorilerine ek olarak, sağlık sektörü çalışanları, hasta bakımı ve ölen hastalardan doğrudan sorumlu olmaktadır [9]. Üstlendikleri sorumluluk ve sonuçların yaşamsal önemi göz önünde bulundurulduğunda sağlık çalışanları için mesleki stres, sadece mesai saatlerinde değil sürekli olarak yaşanan, önemli bir psikolojik risk faktörü haline gelmektedir. Tüm bunlara artan iş yükü ve vardiyalı çalışma biçimleri gibi koşullar da eklendiğinde, psikolojik zorlanmanın kuşkusuz en yüksek seviyede olduğu çalışma ortamlarından biri sağlık bakım hizmetlerinin gerçekleştiği yerlerdir.

Etkili bir hastane çalışanları sağlık programı pek çok hizmeti içermektedir. Hastane Çalışanlarının Sağlık ve Güvenliğinin Değerlendirilmesi İçin Ulusal Mesleki Güvenlik ve Sağlık Enstitüsü (National Institute for Occupational Safety and Health [NIOSH]) Rehberi'nde bu hizmetler; tıbbi öyküyü içeren işe giriş muayenesi, periyodik sağlık muayeneleri, sağlık ve güvenlik eğitimi, bağışıklama, iç hastalıkları ve kazalarından korunma, sağlık önerileri, çevresel kontrol ve gözetim, sağlık ve güvenlik kayıt sistemleri, hastane bölümleri ve servisleri ile eşgüdümlü planlama kategorileri altında gruplandırılmaktadır [10].

Literatürde sağlık sektöründe İSG risklerini ele alan çalışmalar incelendiğinde; kaza türleri, üzerinde durulan bulaş yolları, hangi tür sağlık personelinin araştırmaya dahil edildiği gibi pek çok unsurun değişkenliği dikkat çekmektedir. Sağlık çalışanı kategorisine dahil olan farklı personel grupları, sektörde yer alan meslek mensupları tarafından yürütülen işlerin çeşitliliği ve bunlara bağlı olarak değişen risk faktörleri göz önünde bulundurulduğunda, konunun karmaşık yapısı da anlaşılabilir olmaktadır. Bununla birlikte konuyu çeşitli yönleriyle ele alan tüm bilimsel incelemeler alana sağladıkları katkı nedeniyle değerli çalışmalar olarak görülmektedir.

\section{B. Hastane Birimleri Ayrımında Enfeksiyon Riski İçeren İş} Kazaları

Hastalık Kontrol ve Önleme Merkezi (Centers for Disease Control and Prevention [CDC]) verileri, sağlık çalı- 
şanlarında görülen iğne ucu ve perkütan yaralanmaların sayısının her yıl artış gösterdiğine, ABD'de hastane personelinin günde 1000 kesici-delici alet yaralanması ve yılda ortalama 385.000 enjektör yaralanması yaşadığına, bu yaralanmaların \%60'nın kayıt altına alınmamakta olduğuna işaret etmektedir [11]. 2004 ve 2013 Yılları arasında Birleşik Krallık'ta vücut sıvılarına, toplam 4.830 sağılık bakımı ile ilişkili mesleki maruz kalma vakası bildirilmiştir [12]. Sağlık sektöründe yaşanan kesici delici aletler ve vücut sıvılarıyla temasa bağlı enfeksiyon riskleriyle ilgili önemli bir diğer sorun, bu gibi durumların raporlanması konusunda yaşanmaktadır. Raporlama sistemiyle yalnızca önemli bir enfeksiyona veya yaralanmaya neden olan vakalar kaydedilmiş olduğundan, gerçek rakamların bilinenden çok daha yüksek olması muhtemel görünmektedir. Özellikle gündüz mesai saatleri dışında meydana gelen kazaların kayıtlara geçmediği bilinmektedir [13].

Akdeniz Üniversitesi Hastanesi İş Yeri Sağlığı Güvenliği Birimi’ne yapılan iş kazası bildirim formlarının sınıflandırılması ve analiz edilmesiyle gerçekleştirilen bir çalısmada; doktor, hemşire, sağlık teknisyenlerinden oluşan birinci grup (sağlık çalışanı); mutfak, temizlik, sekreter, büro, danışma ve teknik personelden meydana gelen ikinci bir grup (diğer sağlık çalışanı) halinde kurum çalışanları kategorize edilmiştir. Çalışma bulguları göstermektedir ki; doktor ve hemşirelerin yer aldığı "sağlık çalışanları" olarak isimlendirilen birinci grupta, kesici ve delici alet yaralanmaları \%60; kan ve vücut sıvilarıyla temas etme sonucu kaydedilen kazalar ise \%18'lik bir orana sahiptir. Aynı kaza türlerinin diğer sağlık çalışanı tarafından tecrübe edilmesi oranı ise toplam \%34 olarak tespit edilmiştir (Kesici delici alet yaralanması \%30; sıvı sıçraması \%4) [14].

Mesleki maruziyetin dışında hastanede görev yapılan birimler ayrımında, acil ve cerrahi birimlerde çalışan personelin, diğer birimlerde görev yapanlara oranla daha fazla kesici delici aletlerle yaralandığı ve vücut sıvılarına maruz kaldığı görülmektedir $[15,16]$. Dolayısıyla tehlike gruplarının sadece mesleki sınıflar üzerinden belirlenemeyeceği, hastanenin belli birim ve bölümlerinin özellikle kan ve vücut sıvılarıyla bulaşan patojenler açısından riskli alanlar meydana getirdiği de göz önünde bulundurulmalıdır.

\section{YÖNTEM}

\section{A. Evren ve Örneklem}

Türkiye'de bir üniversite hastanesinde görev yapan hemşireler, kolayda örnekleme yöntemiyle araştırmaya dahil edilmiştir. Hastane personel kayıtlarına göre, araştırma verilerinin toplandığı tarihte, kurum bünyesinde 292 hemşire görev yapmaktadır.

Kolayda örnekleme yoluyla araştırma evreninin (N=292), \%51'ine ulaşılmışır ( $N=149)$. Araştırma örneklemi, $\% 95$ güven düzeyinde araştırma evrenini temsil gücüne sahiptir [17].

\section{B. Veri Toplama Aracı}

Katılımcların demografik verileri; "yaş", "eğitim düzeyi" ve "mesleki tecrübe" ile ilgili sorular yardımıyla toplanmıştır. Katılımcıların kurumda çalışmakta oldukları birimler arasında kan yolu ile bulaşan patojen risk seviyelerinde farklılıklar olabileceği düşünülmektedir. Hastanenin çalışma biçimi göz önünde bulundurularak görev birimleri; ameliyathane, yoğun bakım, servis, poliklinik/gündüz tedavi ve diğer olmak üzere kategorize edilmiştir. Katılımcıların, "Ameliyathane hemşiresi", "Yoğun bakım hemşiresi", "Servis hemşiresi", "Poliklinik/gündüz tedavi hemşiresi” ve "Diğer (yazınız)" seçeneklerinden oluşan, görev kategorilerine dair bilgi vermesi istenmiştir.

Çalışanların son bir sene içerisinde geçirmiş olduğu, kaza türleri; "iğne ile yaralanma", "kesici aletler ile yaralanma", "açık yaraya temas", "göz ya da ağıza sıçramalar" ve 
"diğer" olmak üzere 5 seçenekli bir ifade ile belirlenmiştir. 5 seçenekli soru ifadesi ile kategorize edilen iş kazaları, araştırmada "yaralanma ve enfeksiyon bulaşma riski taşıyan iş kazaları" olarak ifade edilmektedir.

İlk dört grupta yer alan, "iğne ile yaralanma”, "kesici aletler ile yaralanma", "açı yaraya temas" ve "göz ya da ağıza sıçramalar", çalışmada üzerinde durulan "kan ve vücut sıviları yoluyla bulaşan patojen risk içeren kazalar" dır. Sağlık çalışanları kan ve vücut sıvılarıyla bulaşan patojen riskler dışında kimyasal, ergonomik ve biyolojik pek çok risk faktörüne açlk bir ortamda işlerini yerine getirmektedir. Bu nedenle "diğer" seçeneği, hemşirelerin maruz kalabilecekleri farklı kaza türlerinin, araştırmada incelenebilmesi amacıyla seçenekler arasına eklenmiştir.

Yaralanma ve enfeksiyon bulaşma riski taşıyan iş kazaları ile kan ve vücut sıvıları yoluyla bulaşan patojen risk içeren kazaların ölçülmesinde, Gershon ve çalışma arkadaşları (2000)'nın sınıflaması esas alınmıştır [18].

\section{Araştırma Hipotezleri}

Çeşitli araştırmaların sonuçları ameliyathanelerin özellikle kan yoluyla bulaşan hastalıklar açısından riskli ortamlar olduğunu göstermektedir [19]. Şencan ve çalışma arkadaşları (2004)' nın araştırma bulguları, ameliyathane ortamının kazaların en sık yaşandığı yer olduğu sonucunu doğrulamaktadır [20]. Kurumsal veriler ve Dünya literatüründe konuyla ilgili çalışma sonuçları, cerrahi birimlerde çalışan personelin, diğer birimlerde görev yapanlara oranla, özellikle kesici ve delici alet yaralanmaları için daha riskli bir ortamda görev yaptığını işaret etmektedir [16, 15]. Bu araştırmada da hemşirelerin çalışma birimleri ayrımında farklı sıklıklarda kaza deneyimleyecekleri ve özellikle ameliyathane hemşirelerinin kesici ve delici aletlerle yaranma riskinin diğer gruplarda yer alan hemşirelere göre daha fazla olacağı öngörülmektedir. Bu doğrultuda araştırmada aşağıdaki hipotezler üzerinde durulmaktadır:

H1: Ameliyathane Biriminde çalışmakta olan hemşireler, diğer birimlerde çalışmakta olan hemşirelere göre daha sık iğne ile yaralanmaktadır.

H2: Ameliyathane biriminde çalışmakta olan hemşireler, diğer birimlerde çalışmakta olan hemşirelere göre daha sık kesici aletlerle yaralanmaktadır.

\section{BULGULAR}

Araştırma örneklemini meydana getiren 149 hemşirelik mesleği mensubunun eğitim düzeyi; lise $(\% 14,09)$, önlisans $(\% 10,06)$, lisans $(\% 65,77)$, yüksek lisans $(\% 10,06)$ kademelerinde değişmektedir. Kurumda görev yapan katılımcı hemşirelerin yaş ortalaması $32 \pm 4,79$; ortalama mesleki tecrübeleri 9,8 $\pm 4,82$ olarak bulunmuştur.

Tablo 1: Demografik bilgiler

\begin{tabular}{lcc}
\hline Eğitim Düzeyi & $\mathbf{N}$ & $\%$ \\
\hline Lise & 21 & 14,09 \\
Ön Lisans & 15 & 10,06 \\
Lisans & 98 & 65,77 \\
Yüksek Lisans & 15 & 10,06 \\
\hline \multicolumn{2}{c}{ Ortalama } & Std.Sapma \\
\hline Yaş & 32,39 & 4,79 \\
Mesleki Tecrübe (n=149) & 9,81 & 4,82 \\
Örneklem Sayısı (N) & \multicolumn{2}{c}{149} \\
\hline
\end{tabular}

Araştırmada hemşirelik mesleğine mensup katılımcıların çalışmakta oldukları birimler ile ilgili veriler toplanarak analiz edilmiştir. Bu sayede, farklı çalışma alanlarının içerdikleri risk düzeyini incelemek amaçlanmıştır.

Tablo 2: Hemşirelerin çalışma birimleri

\begin{tabular}{lcc}
\hline Birim & N & \% \\
\hline Ameliyathane & 21 & 14,1 \\
Yoğun Bakım & 32 & 21,5 \\
Servis & 71 & 47,7 \\
Poliklinik/Gündüz Tedavi & 18 & 12,1 \\
Diğer & 7 & 4,7 \\
\hline Toplam & 149 & 100 \\
\hline
\end{tabular}


Tablo 2'ye göre ankete katılan 149 hemşirenin \%14,1'i $(\mathrm{N}=21)$ ameliyathanede, $\% 21,5^{\prime} \mathrm{i}(\mathrm{N}=32)$ yoğun bakımda, \%47,7'si ( $\mathrm{N}=71)$ serviste, \%12,1'i $(\mathrm{N}=18)$ poliklinik/ gündüz tedavi hizmetinde, $\% 4,7$ 'si $(\mathrm{N}=7)$ diğer grupta yer almaktadır.

Çalışma birimleri ayrımında hemşirelerin son bir sene içerisinde kazalara maruz kalma oranları ile ilgili bilgiler aşağıdaki gibidir (Tablo 3).

Tablo 3: Hemşirelerin çalışma birimlerine göre kaza verileri

\begin{tabular}{lccc}
\hline & & \multicolumn{2}{c}{ İş Kazasına Maruz Kalma } \\
\cline { 3 - 4 } & & Hayır & Evet \\
\hline \multirow{2}{*}{ Ameliyathane H. } & $\mathbf{N}$ & 6 & 15 \\
& $\%$ & 28,6 & 71,4 \\
Yoğun Bakım H. & $\mathbf{N}$ & 16 & 16 \\
\multirow{2}{*}{ Servis H. } & $\%$ & 50,0 & 50,0 \\
\multirow{2}{*}{ Poliklinik/Gündüz Tedavi H. } & $\mathbf{N}$ & 37 & 34 \\
& $\mathbf{N}$ & 52,1 & 47,9 \\
Diğer & $\mathbf{N}$ & 9 & 9 \\
& $\mathbf{N}$ & 70,0 & 50,0 \\
Toplam & $\%$ & 100,0 & 0 \\
& $\mathbf{N}$ & 75 & 0,0 \\
\hline
\end{tabular}

Tablo 3'e göre ameliyathane hemşirelerinin kaza maruziyetleri diğer hemşirelerden ayrılarak oldukça yüksek düzeyde saptanmıştır. Araştırmaya katılan 21 ameliyathane hemşiresinin 15 'i son bir sene içerisinde bir veya birden fazla kazaya maruz kaldığını belirtmiştir. Ameliyathane hemşirelerinin yaralanma ve enfeksiyon riski taşıyan kaza deneyimleme oranı $\% 71,4$; yoğun bakımda ve poliklinik/ gündüz tedavi hizmetinde görev yapan hemşirelerin \%50; buna oldukça yakın olarak servis hemşirelerinin \%47,9 oranında kazaya maruz kaldıkları tespit edilmiştir. Komite, özel dal vb. görevleri yerine getiren ve "diğer” grup hemşire kategorisine dahil olan hemşirelerde ise son bir sene içerisinde yaşanan herhangi bir kaza verisine rastlanmamıştır. Frekans dağılımı sonuçlarına göre; ameliyathane hemşireleri, diğer birimlerde çalışmakta olan hemşirelere göre daha yüksek düzeyde enfeksiyon riski taşıyan kazaya maruz kalmaktadır.

Araştırmada, Sağlık kurumlarında yaralanma ve enfeksiyon riski taşıyan kazaların kategorik olarak; "İ̆gneyle Yaralanma”, "Kesici Aletlerle Yaralanma”, “Açık Yaraya Temas”, "Göz ya da Ağıza Sıçramalar” ve "Diğer" ayrımına göre yaşanma oranları, hemşirelerin kurumda çalışmakta oldukları birimler göz önünde bulundurularak ayrıca incelenmiştir (Tablo 4).

Tablo 4’e göre, diğer grup kazalar dişında tüm kaza türleri için ameliyathane hemşireleri en yüksek deneyim oranına sahiptir. Son bir yıl içerisinde ameliyathane hemşirelerinin; \%47,6's1 iğneyle yaralanma, \%28,6's1 kesici aletlerle yaralanma, 14,3'ü açık yaraya temas, 38,1'i göz ya da ağıza sıçrama vakası yaşadığını bildirmiştir.

Kaza türleri için birimler ayrımındaki sayısal değerlerin istatistiki açıdan önemli kabul edilebilecek bir farklılığa

Tablo 4: Hemşirelerin çalışma birimleri ayrımında kaza geçirme verileri

\begin{tabular}{|c|c|c|c|c|c|c|c|}
\hline & & Ameliyathane $\mathrm{H}$. & $\begin{array}{c}\text { Yoğun Ba- } \\
\text { kım H. }\end{array}$ & Servis $\mathrm{H}$. & Poliklinik H. & Diğer H & Toplam \\
\hline \multirow{3}{*}{ İğneyle Yaralanma } & & 21 & 32 & 71 & 18 & 7 & 149 \\
\hline & $\mathbf{N}$ & 10 & 12 & 24 & 6 & 0 & 52 \\
\hline & $\%$ & 47,6 & 37,5 & 33,8 & 33,3 & 0,0 & 34,9 \\
\hline \multirow{2}{*}{ Kesici Aletlerle Yaralanma } & $\mathbf{N}$ & 6 & 1 & 6 & 0 & 0 & 13 \\
\hline & $\%$ & 28,6 & 3,1 & 8,5 & 0,0 & 0,0 & 8,7 \\
\hline \multirow{2}{*}{ Açık Yaraya Temas } & $\mathbf{N}$ & 3 & 2 & 7 & 0 & 0 & 12 \\
\hline & $\%$ & 14,3 & 6,3 & 9,9 & 0,0 & 0,0 & 8,1 \\
\hline \multirow{2}{*}{ Göz ya da Ağıza Sıçramalar } & $\mathbf{N}$ & 8 & 9 & 12 & 5 & 0 & 34 \\
\hline & $\%$ & 38,1 & 28,1 & 16,9 & 27,8 & 0,0 & 22,8 \\
\hline \multirow{2}{*}{ Diğer İş Kazaları } & $\mathbf{N}$ & 0 & 2 & 0 & 3 & 0 & 5 \\
\hline & $\%$ & 0,0 & 6,3 & 0,0 & 16,7 & 0,0 & 3,4 \\
\hline
\end{tabular}


sahip olup olmadığı incelenmiştir. Bu amaçla hemşirelerin çalışma birimlerine göre farklılaşan kaza deneyimleri çoklu gruplar için Ki-Kare analizi ile test edilmiştir.

Ameliyathane hemşirelerinin diğer birimlerde çalışan hemşirelerle birlikte değerlendirildiğinde, çeşitli kazaları tecrübe etme sıklığı istatistiksel açıdan incelenmiştir. "Kesici ve delici aletlerle meydana gelen yaralanmalar" olarak; "iğne ile yaralanma" ve "kesici aletlerle yaralanma" vakalarına ilişkin analiz sonuçları Tablo 5 ve 6' da özetlenmektedir.

Tablo 5: Hemşirelerin çalışma birimleri ayrımında kaza deneyimleri için Ki-Kare analizi sonuçları (iğne ile yaralanma)

\begin{tabular}{cccc}
\hline Hipotez & $\begin{array}{c}\text { Ki- } \\
\text { Kare }\end{array}$ & S.D. & p \\
\hline $\begin{array}{c}\text { Ameliyathane biriminde çalışmakta } \\
\text { olan hemşireler, diğer birimlerde } \\
\text { çalışmakta olan hemşirelere göre daha } \\
\text { sık iğne ile yaralanmaktadır. }\end{array}$ & 5,400 & 4 &, 249 \\
\hline
\end{tabular}

Tablo 6: Hemşirelerin çalışma birimleri ayrımında kaza deneyimleri için Ki-Kare analizi sonuçları (kesici aletlerle yaralanma)

\begin{tabular}{cccc}
\hline Hipotez & Ki-Kare & S.D. & p \\
\hline $\begin{array}{c}\text { Ameliyathane biriminde çalış- } \\
\text { makta olan hemşireler, diğer } \\
\text { birimlerde çalışmakta olan hem- } \\
\text { şirelere göre daha sık kesici } \\
\text { aletlerle yaralanmaktadır. }\end{array}$ & 14,043 & 4 &, $007^{* *}$ \\
\hline
\end{tabular}

Analiz sonuçlarına göre ameliyathane hemşirelerinin, kesici aletlerle yaralanma vakasında anlamlı bir farkla daha sık kaza deneyimlediği bulgulanmıştır $(\mathrm{p}<0,05)$ (Tablo 6). İğne ile yaralanma vakasında ise ameliyathane hemşireleri için, diğer gruplarda yer alan hemşirelere göre istatistiki açıdan anlamlı sayılabilecek bir farklılık tespit edilmemiştir $(\mathrm{p}>0,05)$ (Tablo 5).

\section{SONUÇ VE DEĞERLENDİRMELER}

Çeşitli araştırmaların sonuçları ameliyathanelerin özellikle kan ve vücut sıvıları yoluyla bulaşan hastalıklar açısından riskli ortamlar olduğunu göstermektedir [19]. Çalışma birimleri ayrımında hemşirelerin son bir sene içerisinde kazalara maruz kalma düzeyleri incelendiğinde; ameliyathane hemşirelerinin kaza deneyimleme oranları diğer hemşirelerden ayrılarak oldukça yüksek düzeyde saptanmıştır. Araştırmaya katılan 21 ameliyathane hemşiresinin $15^{\prime}$ i son bir sene içerisinde bir veya birden fazla kazaya maruz kald1ğını belirtmiştir (Tablo 3). Kan ve vücut sıvıları yolu ile bulaşan patojen risk içeren tüm kaza türleri için ameliyathane hemşirelerinin en yüksek yaralanma oranına sahip olduğu görülmüştür (Tablo 4). Buna göre, sağlık profesyonelleri için, hastane ortamında ameliyathanelerin yüksek iş kazası riski barındıran bir çalışma alanı olduğu sonucu doğrulanmaktadır.

Frekans dağılımları iğne ile yaralanma vakalarıyla ameliyathane hemşirelerinin daha sık karşılaştığını göstermektedir. Fakat sayısal farklılık, istatistiki olarak anlamlı bulunmamış ve H1 reddedilmiştir (Tablo 5). Bununla birlikte, kesici aletler ile yaralanma vakasında ameliyathane hemşirelerinin, diğer gruptaki hemşirelere göre istatistiksel aç1dan anlamlı düzeyde daha fazla yaralanma yaşadığı sonucuna ulaşılmıştır (Tablo 6). Böylelikle çalışmada, ameliyathane hemşireleri ile diğer hemşirelerin kesici aletlerle yaralanma deneyimlerinin anlamlı biçimde farklılaşacağı yönündeki araştırma hipotezi doğrulanmıştır $(\mathrm{H} 2)$.

Literatürde sağlık çalışanlarının yaralanma ve enfeksiyon bulaşma riski taşıyan kaza deneyimleri konusunda yürütülen diğer çalışmalar incelendiğinde, "iğne ile yaralanma" ve "kesici aletlerle yaralanma" vakaları birçok çalışmada "kesici ve delici aletlerle yaralanma" kapsamında bir arada değerlendirilmiştir $[11,13,14,15,16]$. Yürütülen çalışmada iki yaralanma türü ayrı olarak ele alındığında “iğne ile yaralanma” vakası için; ameliyathane, yoğun bakım, servis/poliklinik ve diğer birimlerde yaşanan kaza sıklığı ile ameliyathane biriminde yaşanan kaza sıklıkları arasında istatistiksel açıdan anlamlı bir farklılık olmadığı 
sonucuna varılmıştır. Bununla birlikte "Diğer" kazalar dışında, "iğne ile yaralanma”, "kesici aletler ile yaralanma”, “açık yaraya temas” ve "göz ya da ağıza sıçrama” kategorilerinde ölçülen tüm kaza biçimlerini En yüksek oranda deneyimleyen çalışan grubu ameliyathane hemşireleridir (Tablo 4).

Çalışma anketinde kan ve vücut sıvıları yoluyla bulaşan patojen risk içeren kazalar olarak sınıflandırılan dört grup kazanın (iğne ile yaralanma, kesici aletler ile yaralanma, açık yaraya temas ve göz ya da ağıza sıçrama) ameliyathane hemşireleri tarafından daha sık deneyimlendiği bulgulanmıştır. Özellikle kesici aletlerle yaralanma vakası, ameliyathane hemşireleri tarafından diğer birimlerde çalışmakta olan hemşirelere göre istatistiksel olarak anlamlı biçimde daha fazla tecrübe edilmektedir. Kurumsal veriler ve konuyla ilgili çalışma sonuçlarına paralel olarak, cerrahi birimlerde çalışan personelin, diğer birimlerde görev yapanlara oranla daha riskli bir ortamda görev yaptığı böylece doğrulanmış olmaktadır $[16,20,15]$.

Sağlık çalışanlarının karşı karşıya olduğu riskler; diğer sektörlerden büyük ölçüde farklılaşmaktadır. Bununla birlikte sağlık çalışanı kategorisine dahil olan hasta bakıcı, teknisyen, idari personel, doktor ve hemşireler tarafından yerine getirilen görevlere ve hastanede görev yapılan birime bağlı olarak farklı güvenlik riskleri ön plana çıkmaktadır. Dolayısıyla sağlık alanında önleyici İSG uygulamalarının sadece diğer sektörlerden ayrı olarak ele alınması yeterli olmamakta, aynı zamanda her bir birim, uzmanlık alanı, görev yükümlülüğü ve meslek grubu için ayrıca risk değerlendirmeleri, güvenlik programları ve önlemleri üzerinde durulmalıdır.

İSG ile ilgili önlemlerin, kalite yönetimi ve stratejiyle birleştirilmesiyle, hastaneler ya da tıbbi bakım merkezlerinin başarısının destekleneceği düşünülmektedir. Hastane- nin bakım kalitesi ve ekonomik verimliliği üzerinde, önlemlerin olumlu etkilerini izleyebilmek için; kalite yönetiminde belirlenen kriterler ile İSG verileri birlikte ele alınmalıdır [2]. Bu nedenle sağlık sektörü çalışanlarının çalışma ortamında karşı karşıya kaldıkları güvenlik tehditlerinin incelenmesi, doğru risk değerlendirme faaliyetlerinin yürütülmesi ve önleyici adımların atılabilmesi için ön koşul niteliğindedir.

ÇıKaR ÇATışMası: Araştırmada herhangi bir çıkar çatışması olmayıp, makalede araştırma ve yayın etiğine uygun biçimde hareket edilmiştir.

Finansal Destek: Bu çalışmada herhangi bir kişi, kurum veya kuruluştan finansal destek alınmamıştır.

Eтiк Комітte Onayı: "Çalışma için 01.07.2016 tarihinde (Protokol No:148) Zonguldak Bülent Ecevit Üniversitesi İnsan Araştırmaları Etik Kurulu'ndan onay alınmıştır.

\section{KAYNAKÇA}

[1] Sabuncuoğlu, Z. (2013). Uygulamalı Örnekleriyle İnsan Kaynakları Yönetimi. Beta Yayınevi, İstanbul.

[2] Europeon Commission. (2014). Sağlık Sektöründe İş Sağlığı ve Güvenliği Riskleri. (Çev: Prof.Dr. Mithat Kıyak), Okan Üniversitesi Yayınları, İstanbul.

[3] Resmi Gazete. (20 Haziran 2012). 6331 Sayılı İş Sağlığı ve Güvenliği Kanunu, Sayı: 28339. Erişim Tarihi: 2.04.2018, http://www.resmigazete.gov.tr

[4] Resmi Gazete. (25 Kasım 2009). İş Sağlığı ve Güvenliğine İlişkin İşyeri Tehlike Sınıfları Tebliği, Sayı: 27417. Erişim Tarihi: 2.04.2018, http:// www.resmigazete.gov.tr

[5] Resmi Gazete. (6 Nisan 2011). T.C. Sağlık Bakanl1ğı. Hasta ve Çalışan Güvenliğinin Sağlanmasına Dair Yönetmelik, Sayı: 27897. Erişim Tarihi: 5.04.2018. http://www.resmigazete.gov.tr

[6] Meydanlioglu, A. (2013). Sağlık çalışanlarının sağlık ve güvenliği, Balıkesır Health Sciences Journal, 2(3), 192-199.

[7] Ulutaşdemir, N., Cirpan, M., Copur-Ozturk, E. \& Tanir, F., (2015). Occupational risks of health professionals in Turkey as an emerging economy. Annals 
of Global Health, 81(4), 522-529.

[8] OSHA. (Eylül, 2013). Fact About Hospital Worker Safety. Erişim Tarihi: 19.04.2017, https:// www.osha.gov/sites/default/ files/1.2_Factbook_508.pdf.

[9] Wilburn, S.Q. \& Eijkemans, G. (2004). Preventing Needlestick injuries among healthcare workers: a WHO-ICN collaboration. International Journal of Occupational and Environmental Health, 10(4), 451 $-456$.

[10] NIOSH Guidelines for Evaluation of Hospital Occupational Health and Safety Programs/ Hastane Çalışanlarının Sağlık ve Güvenliğinin Değerlendirilmesi İçin Ulusal İş Güvenliği ve Sağlığı Enstitüsü Rehberi (2003). (Çev: İlhan M.N.). Mesleki Sağlık ve Güvenlik Dergisi, 4(13), 46-47.

[11] Dikmen, U.A., Medeni, V., Uslu, İ. \& Aycan, S. (2014). Ankara'da bir üniversite hastanesinde çalışan sağlık personelinin geçirdiğini ifade ettiği iş kazalarının değerlendirilmesi. Türk Tabipleri Birliği Mesleki Sağlık ve Güvenlik Dergisi, 14(53), 22-29.

[12] Woode-Owusu, M., Wellington, E., Rice, B., Ncube, F. \& contributors. (2014). Eye of the needle. United Kingdom surveillance of significant occupational exposure to bloodborne viruses in healthcare workers. Public Health England. Erişim Tarihi: 17.12.2020, www.gov.uk/government/uploads/system/uploads/ attachment_data/file/385300/EoN_2014__FINAL_CT_3_sig_occ.pdf.

[13] Riddell, A., Kennedy, I. \& Tong, C.Y.W. (2015). Management of sharps injuries in the healthcare setting. Clinical Review, 351(4), 223-229.

[14] İnci, E.İ., Bilişli, Y. \& Hizay, D. (2016). İş kazalarına maruz kalan sağlık çalışanlarının bildirimlerinin değerlendirilmesi: üniversite hastanesi örneği. Sağlık Akademisyenleri Dergisi, 3(3), 83-88.

[15] Sahio, J, Gou, L. \& McLaws, M. L. (2002). Estamination of the risk of bloodborne pathogens to health care workers after a needlestick injury in Taiwan. American Journal of Infection Control, 30(1), 15-20.

[16] CDC. (2008). Sharp injuryprevention program workbook 2008. Erişim Tarihi: 8.02.2019, http:// www.cdc.gov/Sharpssafety/pdf/sharpsworkbook 2008.pdf.

[17] Sekaran, U. (2003). Research methods for business a skill-building approach, fourth edition. Southern Illinois University at Carbondale.

[18] Gershon, R.R.M., Karkashian, C.D., Grosch, J.W. et al. (2000). Hospital safety climate and its relationship with safe work practices and workplace exposure incidents. Am J Infect Control (AJIC), 28(3), 211-221.

[19] Akgün, S. (2015). Sağlık sektöründe iş kazaları . Sağlık Akademisyenleri Dergisi, 2(2), 67-75. Erişim Tarihi: 10.12.2019, https://dergipark.org.tr/en/pub/ sagakaderg/issue/46750/586379

[20] Şencan, İ., Sahin, İ., Yildirim, M. \& Yeşildal, N. (2004). Unrecognized abrasions and occupational exposures to blood-borne pathogens among health care workers in Turkey. Occupational Medicine, 54 (3), 202-206. 